\title{
A Novel Application of Ti-Substituted Polyoxometalates: Anti-Inflammatory Activity in OVA-Induced Asthma Murine Model
}

\author{
Dong Li, ${ }^{1}$ Xiuzhu Gao, ${ }^{2}$ Jingmin Gu, ${ }^{3}$ Yuan Tian, ${ }^{1}$ Yaqing Liu, ${ }^{1}$ \\ Zheng Jin, ${ }^{1}$ Dongmei Yan, ${ }^{1}$ Ya-Guang Chen, ${ }^{4}$ and Xun $\mathrm{Zhu}^{1}$ \\ ${ }^{1}$ Department of Immunology, College of Basic Medical Sciences, Jilin University, Changchun 130021, China \\ ${ }^{2}$ Department of Hepatology, First Hospital of Jilin University, Changchun 130021, China \\ ${ }^{3}$ College of Veterinary Medicine, Jilin University, Changchun 130062, China \\ ${ }^{4}$ Key Laboratory of Polyoxometalates Science of Ministry of Education, Faculty of Chemistry, \\ Northeast Normal University, Changchun 130024, China
}

Correspondence should be addressed to Dong Li; lidong1@jlu.edu.cn, Ya-Guang Chen; chenyg146@nenu.edu.cn, and Xun Zhu; zxunzhux@vip.sohu.com

Received 18 March 2016; Revised 17 May 2016; Accepted 29 May 2016

Academic Editor: Anastasios Keramidas

Copyright (C) 2016 Dong Li et al. This is an open access article distributed under the Creative Commons Attribution License, which permits unrestricted use, distribution, and reproduction in any medium, provided the original work is properly cited.

Objective. Asthma is a chronic inflammatory disorder. Despite extensive researches into the treatment and management of it, current treatments and management strategies are still limited. The search for a novel approach to its treatments is urgently needed. Researches on the potential medical use of polyoxometalates (POMs) have already shown it has antiviral and antitumor bioactivities. But the effects of POM in immune systems are still largely unknown. Methods. In order to investigate the role of POM in the asthmatic disease, we used OVA-induced asthma murine model and observed the pathological changes between mice that received three different Ti-substituted POMs $(0.3 \mu \mathrm{g}$ per mouse per dose) when challenged with OVA. We also measured the type 2 cytokine expressions to reveal the potential mechanism. Results and Conclusions. Our results showed that two Ti-substituted POMs, $\mathrm{K}_{5} \mathrm{H}_{2}\left[\mathrm{FeW}_{11} \mathrm{TiO}_{40}\right] \cdot 17 \mathrm{H}_{2} \mathrm{O}$ and $\mathrm{K}_{5} \mathrm{H}\left[\mathrm{H}_{2} \mathrm{ZnW}_{11} \mathrm{TiO}_{40}\right] \cdot 35 \mathrm{H}_{2} \mathrm{O}$, could reduce OVA-induced lung inflammation, serum IgE level (around $2000 \mathrm{ng} / \mathrm{mL}$ to less than $1000 \mathrm{ng} / \mathrm{mL}$ ), leukocytes infiltration in the lung, and cytokines levels (including IL-4, IL5 , IL-13, and TNF- $\alpha$ ) but Ti-centered POM K $\mathrm{K}_{4}\left[\mathrm{TiW}_{12} \mathrm{O}_{40}\right] \cdot 10 \mathrm{H}_{2} \mathrm{O}$ did not. Thus, Ti-substituted POMs may have pharmaceutical values especially in treatments for asthmatic diseases.

\section{Introduction}

Polyoxometalates (POMs) are a kind of negatively charged inorganic substances constructed by early transitional metal ions such as vanadium $(\mathrm{V})$, niobium $(\mathrm{Nb})$, molybdenum (Mo), and tungsten (W). The most typical and fully studied POMs are those with Keggin anion structure, $\mathrm{XM}_{12} \mathrm{O}_{40}{ }^{n-}$, $\mathrm{M}=\mathrm{Mo}, \mathrm{W} ; \mathrm{X}=\mathrm{B}, \mathrm{Al}, \mathrm{Ga}, \mathrm{Si}, \mathrm{Ge}, \mathrm{P}, \mathrm{As}, \mathrm{Ti}, \mathrm{V}, \mathrm{Cr}, \mathrm{Fe}$, $\mathrm{Co}, \mathrm{Ni}, \mathrm{Cu}, \mathrm{Zn}$, and so forth; $\mathrm{X}$ is called as heteroatom or central atom, due to its relative stability and easy availability, as well as potential application in catalysis, medicine, and materials $[1,2]$. One $\mathrm{M}$ atom in the anion may be replaced by other metal atoms, giving so-called monosubstituted POM.
The metal substitution extends considerably the number of POMs and modified the properties of the anions. In this field, there are much reports about the substituted POM with main group elements such as $\mathrm{Si}$ and $\mathrm{P}$ as heteroatom, and those with transition elements as $\mathrm{X}$ were reported relatively less [3-5], although $\mathrm{CoW}_{11} \mathrm{CoO}_{40} \mathrm{H}_{2}{ }^{8-}$ was described in 1960s [6].

In the aspect of application in medicine of POMs, three types of POM bioactivities, antiviral, antitumor, and antibacterial, have been reported [7-11]. The third aspect developed later than the former two [12]. The POM with Keggin, lacunary Keggin, Wells-Dawson, double-Keggin, and Kegginsandwich structures enhanced the antibacterial activity of $\beta$-lactam antibiotics on methicillin-resistant Staphylococcus 
aureus $[12,13]$. The mechanism of the synergistic effect by the POM is discussed in terms of the depression of penicillinbinding protein 20 (PBP20) coded by mecA gene [14]. On the other hand, in bioactivity study of substituted POMs, only several Ti-substituted POMs with Keggin (or Kegginsandwich) structure exhibit obvious antiviral and antitumor activity [15-18]. Titanium seems to be an important metal ion to afford antiviral action of POM in mice [17] and titanium-containing POMs were less toxic for actively growing cells than their vanadium containing counterparts [15]. Thus, titanium-containing POM may be safe and potent for therapeutic use in in vivo virus infections. Up to date, there are few reports about the study on antibacterial or antiinflammation activity of Ti-substituted POM.

Asthma is major thread in public health as it affects more than 300 million people worldwide [19, 20]. Asthma, especially allergic allergen induced asthma, is associated with airway eosinophilic inflammation and increased serum $\operatorname{IgE}$ level [21, 22]. Although there were extensive experimental and human studies about the mechanisms of asthmatic airway inflammation and remodeling, more work is still required to fully understand the mechanisms of asthmatic diseases [23]. At present, it is generally believed that the type 2 helper T cell (Th2) cytokines (including interleukin- (IL-) 4, IL-5, and IL13), also known as type 2 cytokines since the major source of them are Th2 cells, and type 2 innate lymphoid cells [24] play an essential role in the pathogenesis of asthma $[25,26]$.

Although asthma symptoms can be controlled in most of the patients by current standard therapies, for example, inhaled corticosteroids like $\beta 2$-adrenergic receptor agonists and oral leukotriene inhibitors [27], there are still around $10 \%$ of patients that are not responsive to these treatments, as they still suffer from bronchial hyperresponsiveness and limitations in airflow. Furthermore, those patients with uncontrolled asthma have higher risk of morbidity and mortality rate [28], and they require the largest share of economic resources and healthcare systems. Therefore, the search for additional therapeutic approaches is urgently needed. In this work we used the OVA-induced asthma murine model to investigate the effect and mechanisms of Ti-substituted POM in asthmatic diseases.

\section{Materials and Methods}

2.1. Chemicals and Instruments. All reagents were commercially available and used without any previous purification. Elemental analyses of $\mathrm{W}, \mathrm{Zn}, \mathrm{Fe}$, and Ti were carried out with a Leeman ICP spectrometer. Thermogravimetric analyses were carried out by using a NETZSCH STA 449 F3 instrument, with a heating rate of $10^{\circ} \mathrm{C} \cdot \mathrm{min}^{-1}$ under a nitrogen atmosphere. The IR spectra in $\mathrm{KBr}$ pellets were recorded in the range of $400-4000 \mathrm{~cm}^{-1}$ with a Magna-560 FT/IR spectrophotometer. The UV spectra were recorded on a TU1810 ultraviolet-visible spectrophotometer in aqua solution.

2.2. Synthesis. $\mathrm{K}_{4}\left[\mathrm{TiW}_{12} \mathrm{O}_{40}\right] \cdot 10 \mathrm{H}_{2} \mathrm{O}$ (TiW): $\mathrm{Na}_{2} \mathrm{WO}_{4} \cdot 2 \mathrm{H}_{2} \mathrm{O}(36.3 \mathrm{~g}$, $0.11 \mathrm{~mol}$ ) was dissolved into $100 \mathrm{~mL}$ of distilled water; then glacial acetic acid was added until the $\mathrm{pH}$ of the solution reached 6.3. The solution was incubated at $60^{\circ} \mathrm{C}$ for $0.5 \mathrm{~h}$. Afterwards, $20 \mathrm{~mL}$ solution containing $4.8 \mathrm{~g} \mathrm{Ti}\left(\mathrm{SO}_{4}\right)_{2}(\mathrm{pH}=$ $1.0,0.02 \mathrm{~mol}$ ) was added under stirring. The resulting solution was then heated at $80-90^{\circ} \mathrm{C}$ for $4 \mathrm{~h}$. After the reaction solution was cooled to room temperature, $7.5 \mathrm{~g}$ solid $\mathrm{KCl}(0.1 \mathrm{~mol})$ was added to the solution. The oil phase was formed while the solution was cooled to $4^{\circ} \mathrm{C}$, and the solution was kept at $4^{\circ} \mathrm{C}$; four days later the oil solidified and the separated solid was treated with warm water. The TiW yield was $20 \%$. Element analysis calculation values for $\mathrm{H}_{20} \mathrm{~K}_{4} \mathrm{O}_{50} \mathrm{TiW}_{12}(\mathrm{Mw}=$ 3230.6): $\mathrm{K} 4.84 \%$, $\mathrm{Ti} 1.48 \%$, W $68.29 \%$ and $\mathrm{H}_{2} \mathrm{O} 5.57 \%$; found values $\mathrm{K} 4.62 \%$, Ti $1.37 \%$, W 69.1\% and $\mathrm{H}_{2} \mathrm{O} 6.5 \%$. IR (in $\mathrm{KBr}$ pellet, $\mathrm{cm}^{-1}$ ): 3433 (s), $1629(\mathrm{~m}), 964(\mathrm{~s}), 882(\mathrm{~m}), 796$ (m), $741(\mathrm{~m}), 425(\mathrm{~m})$.

$\mathrm{K}_{5} \mathrm{H}_{2}\left[\mathrm{FeW}_{11} \mathrm{TiO}_{40}\right] \cdot 17 \mathrm{H}_{2} \mathrm{O}$ (FeWTi) was prepared as previously described [3] and checked by IR spectroscopy and thermogravimetric analysis. Element analysis calculation values for $\mathrm{FeH}_{36} \mathrm{~K}_{5} \mathrm{O}_{57} \mathrm{TiW}_{11}(\mathrm{Mw}=4512.59)$ : $\mathrm{K}$ 6.0, $\mathrm{Fe} 1.7 \%$, Ti 1.5\%, W 61.9\% and $\mathrm{H}_{2} \mathrm{O} 9.9 \%$; found: $\mathrm{K} 6.2 \%$, Fe $1.8 \%$, Ti $1.4 \%, \mathrm{~W} 62.1 \%$ and $\mathrm{H}_{2} \mathrm{O} 10.2 \%$. IR ( $\mathrm{KBr}$ pellet, $\mathrm{cm}^{-1}$ ): 3433 (s), $1629(\mathrm{~m}), 933(\mathrm{~s}), 872(\mathrm{~m}), 7769(\mathrm{~m}), 717(\mathrm{~m}), 425(\mathrm{~m})$.

$\mathrm{K}_{5} \mathrm{H}\left[\mathrm{H}_{2} \mathrm{ZnW}_{11} \mathrm{TiO}_{40}\right] \cdot 35 \mathrm{H}_{2} \mathrm{O}(\mathrm{ZnWTi})$ was prepared as previously described [4] and checked by IR spectroscopy and thermogravimetric analysis. Element analysis calculation values for $\mathrm{H}_{73} \mathrm{~K}_{5} \mathrm{O}_{75} \mathrm{TiW}_{11} \mathrm{Zn}(\mathrm{Mw}=3604.64)$ : $\mathrm{K} 5.42 \%$, Ti $1.33 \%, \mathrm{Zn} 1.81 \%$, W $56.1 \%$ and $\mathrm{H}_{2} \mathrm{O} 18.0 \%$; found: $\mathrm{K} 5.32 \%$, $\mathrm{Ti}$ $1.37 \%$, $\mathrm{Zn} 1.91 \%$, W $56.81 \%$ and $\mathrm{H}_{2} \mathrm{O} 17.9 \%$. IR (KBr, pellet, $\left.\mathrm{cm}^{-1}\right)$ : 3445 (s), $1631(\mathrm{~m}), 933$ (s), 867 (m), 757 (m), 690 (m).

\subsection{Stability of the Compounds in Aqua Solution. Keggin} structure anions of polyoxotungstates have a characteristic absorption band at about $260 \mathrm{~nm}$ in their UV spectra [4]. The intensity of this band of monovacant or monosubstituted Keggin structure anions becomes lower but still can be used for identification of the anions. The absorption curves of three compounds in fresh and stock $\left(0.01 \mathrm{~mol} \cdot \mathrm{L}^{-1}\right)$ aqua solutions of $\mathrm{pH}=4-7$ were recorded in $200-400 \mathrm{~nm}$. The maximum wavelengths for absorbance are TiW $259 \mathrm{~nm}$, ZnWTi $256 \mathrm{~nm}$, and FeWTi $257 \mathrm{~nm}$. The absorption bands of the anions are unchanged in the range of $\mathrm{pH}=5-7$, under which the bioactivity experiments are carried out. The solutions of three compounds with $\mathrm{pH}=6$ gave the same absorption curves after 7 days.

2.4. Mice. Specific-pathogen-free male C57BL/6 mice weighing 18 to $22 \mathrm{~g}$ (purchased from Beijing Weitonglihua Laboratory Animal Co., Ltd., Beijing, China) were housed in specific-pathogen-free conditions at Jilin University, China. All experiments were performed in accordance with the National Guidelines for Experimental Animal Welfare and with approval of the Animal Welfare and Research Ethics Committee at Jilin University.

2.5. Enzyme-Linked Immunosorbent Assay. The concentrations of cytokines in BAL fluid and IgE in serum were determined by enzyme-linked immunosorbent assay (ELISA, 
eBioscience, Inc., CA, US) according to manufacturers' instructions as described previously $[29,30]$.

2.6. OVA-Induced Mice Asthma Model. Mice were given i.p. injections with $100 \mathrm{mg}$ of OVA (ovalbumin, Sigma-Aldrich, $\mathrm{MO}, \mathrm{US}$ ) in $2 \%$ alum (Aluminium Hydroxide Gel Adjuvant, Brenntag, Denmark) and then challenged i.n. on days 8, 9, and 10 with $10 \mathrm{mg}$ of OVA or PBS as described previously $[31,32]$. POMs $(0.3 \mu \mathrm{g}$ per mouse per dose $)$ were injected to mice on days 8,9 , and 10 as the same time with OVA or PBS together. Mice were sacrificed $48 \mathrm{~h}$ after the last challenge by the i.p. injection of $500 \mu \mathrm{L}$ of Avertin $(20 \mathrm{mg} / \mathrm{mL} \mathrm{2,2,2-}$ tribromoethanol, Sigma-Aldrich, MO, US). Bronchoalveolar lavage fluid (BALF) was collected and analyzed as previously described [29].

2.7. Quantitative PCR. RNA was purified from tissue samples using the RNeasy Mini Kit following the manufacturer's instructions as described previously (Qiagen, UK) [29, 30]. Reverse Transcription (RT) of RNA into cDNA was carried out using High-Capacity cDNA Reverse Transcription Kits (Applied Biosystems, CA, US). Real-time polymerase chain reaction (RT-PCR) was performed using Fast SYBR Green Master Mix on a Prism 7900HT (Applied Biosystems, CA, US). The primers used were as follows: $I l 4$, forward $5^{\prime}$-CAT GGC TTG GGT ACA GGT CT-3', reverse 5' -TTT GTA GTG GGA GGG GAC AG-3'; Il5, forward $5^{\prime}$-GAA GTG TGG CGA GGA GAG AC-3', reverse $5^{\prime}$-GCA CAG TTT TGT GGG GTT TT-3' ; Il13, forward 5' -GAA TCC AGG GCT ACA CAG AAC- $3^{\prime}$, reverse $5^{\prime}$-AAC ATC ACA CAA GAC CAG ACT C-3'; Ifng, forward $5^{\prime}$-ACT TTG CTT CTG CCT TTC CA-3', reverse $5^{\prime}$-ACA AGG TCA CCC ACA GGA-3'; Tnf, forward $5^{\prime}$-TCC CCT TCA TCT TCC TCC TT-3', reverse $5^{\prime}$ CAT GCG TCC AGC TGA CTA AA-3'.

2.8. Histologic Analysis. The larger left lung lobe was excised, fixed in $4 \%$ buffered formalin, and embedded in paraffin. Sections $(4 \mathrm{~mm})$ were stained with hematoxylin and eosin (CellPath, Newtown, UK) [29]. The pathology score (from 1-4) was determined by using the method modified from a previous report [33], briefly, a numerical value was assigned based on the number of inflammatory cell infiltrate layers around the blood vessels and airways (1, no cells; $2,<3$ cell layers; 3, 4-9 cell layers; 4, >10 cell layers).

2.9. Bone Marrow-Derived Mast Cells. Bone marrow-derived MC (BMMC) were generated from 7-9-week-old mice by isolating bone marrows from femurs. Cells were then cultured in IMDM (Invitrogen, MA, US) supplemented with 10\% FBS, nonessential amino acids, $50 \mathrm{mM}$ 2-ME (Sigma-Aldrich, MO, US), and $3 \mathrm{ng} / \mathrm{mL}$ IL-3 (PeproTech, NJ, US) for 4 weeks.

2.10. Degranulation Assays. For assessment of MC degranulation, degranulation assays were performed. Briefly, $1 \times$ $10^{6} / \mathrm{mL}$ BMMC were loaded with $1 \mu \mathrm{g} / \mathrm{mL}$ anti-DNP IgE (Sigma-Aldrich, MO, US) in culture medium without IL-3 overnight. Then, cells were washed three times in Modified Tyrode's Buffer (135 mM NaCl, $5 \mathrm{mM} \mathrm{KCl,} 1 \mathrm{mM} \mathrm{MgCl}_{2}$,
$10 \mathrm{mM}$ HEPES, $5.6 \mathrm{mM}$ dextrose, and 0.1\% (w/v) BSA) and then triggered for $60 \mathrm{~min}$ at $37^{\circ} \mathrm{C}$ with stimulation buffer (5 nM PMA (Sigma-Aldrich, MO, US) with $2 \mu \mathrm{M}$ ionomycin (Sigma-Aldrich, MO, US)) at $4 \times 10^{6}$ cells $/ \mathrm{mL}$. To evaluate the inhibition effects of polyoxometalate, $1-100 \mu \mathrm{g} / \mathrm{mL} \mathrm{WTi}$, FeWTi, or ZnWTi was also added in the stimulation buffer, respectively. After stimulation, the concentration of histamine in supernatants was measured by ELISA (Immundiagnostik AG, Bensheim, Germany). And the inhibition rate was calculated by dividing the concentration of histamine in supernatants from mast cells that received POMs by the concentration of histamine in supernatants from mast cells that did not receive POMs.

2.11. Statistical Analysis. Analysis between in vivo groups was examined by Mann-Whitney $U$ test or ANOVA followed by Student's $t$-test. All data are expressed as means \pm SEM. Values of $p<0.05$ were considered significant.

\section{Results}

3.1. Polyoxometalates FeWTi and ZnWTi Attenuate OVAInduced Lung Inflammation. Given the well-established contribution of POM in the activation, proliferation, or suppression of immune cells, we reasoned that certain POMs like $\mathrm{K}_{4} \mathrm{H}\left[\mathrm{H}_{2} \mathrm{FeW}_{11} \mathrm{TiO}_{40}\right] \cdot 17 \mathrm{H}_{2} \mathrm{O}$ (FeWTi) or $\mathrm{K}_{5} \mathrm{H}\left[\mathrm{H}_{2} \mathrm{ZnW}_{11} \mathrm{TiO}_{40}\right] \cdot 35 \mathrm{H}_{2} \mathrm{O}$ (ZnWTi) but not TiW may reduce OVA-induced asthma in mice. To evaluate the effect of these chemicals in asthma, mice were sensitized with OVA plus adjuvant or PBS on day 1 ; then the mice were challenged with OVA or PBS for three times on days 8, 9, and 10; finally all the mice were sacrificed 48 hours after the last challenge, and FeWTi, ZnWTi, or TiW ( $0.3 \mu$ g per mouse) were injected intranasally at the same time with challenges. Mice that received POM alone could not develop lung inflammation, but in OVA sensitized and challenged groups, mice that received FeWTi or ZnWTi had significantly less severe lung inflammation compared to mice that received TiW (Figures 1(a) and 1(b)). FeWTi or ZnWTi treatment was also with lower IgE serum levels compared with TiW groups (Figure 1(c)).

3.2. Polyoxometalates FeWTi and ZnWTi Reduce Inflammatory Cells Infiltrations. After we established that FeWTi or ZnWTi treatment contributed to less severe lung inflammation in OVA-induced asthma mouse model, we next investigated the inflammatory cell infiltration in the airway by performing cellular analysis on the bronchoalveolar lavage fluid (BALF). Compared with TiW treated mice, FeWTi or ZnWTi treated mice showed decreased inflammatory cell infiltration in the BALF (Figure 2(a)), especially neutrophils. Lymphocyte and eosinophil numbers are significantly reduced in FeWTi or ZnWTi treated mice than in TiW treated mice (Figures 2(c) and 2(e)), but the number of macrophages is not significantly different among groups (Figures 2(b) and 2(d)). 

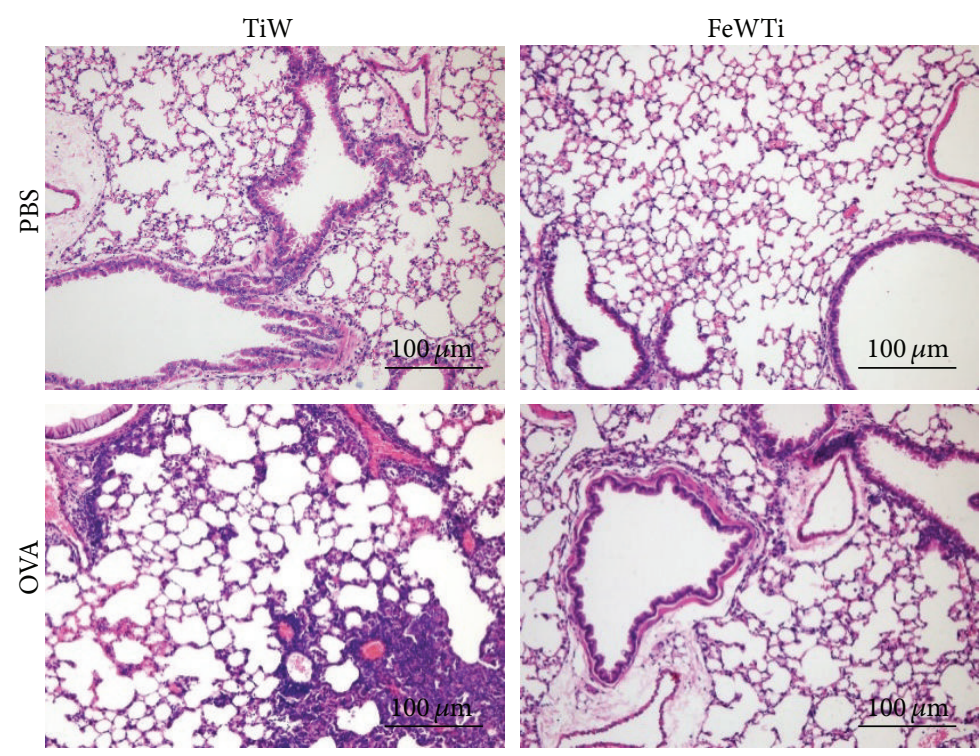

FeWTi

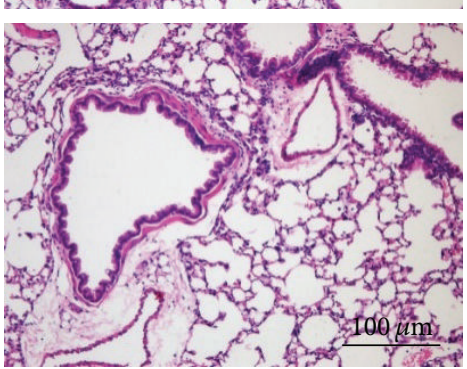

(a)
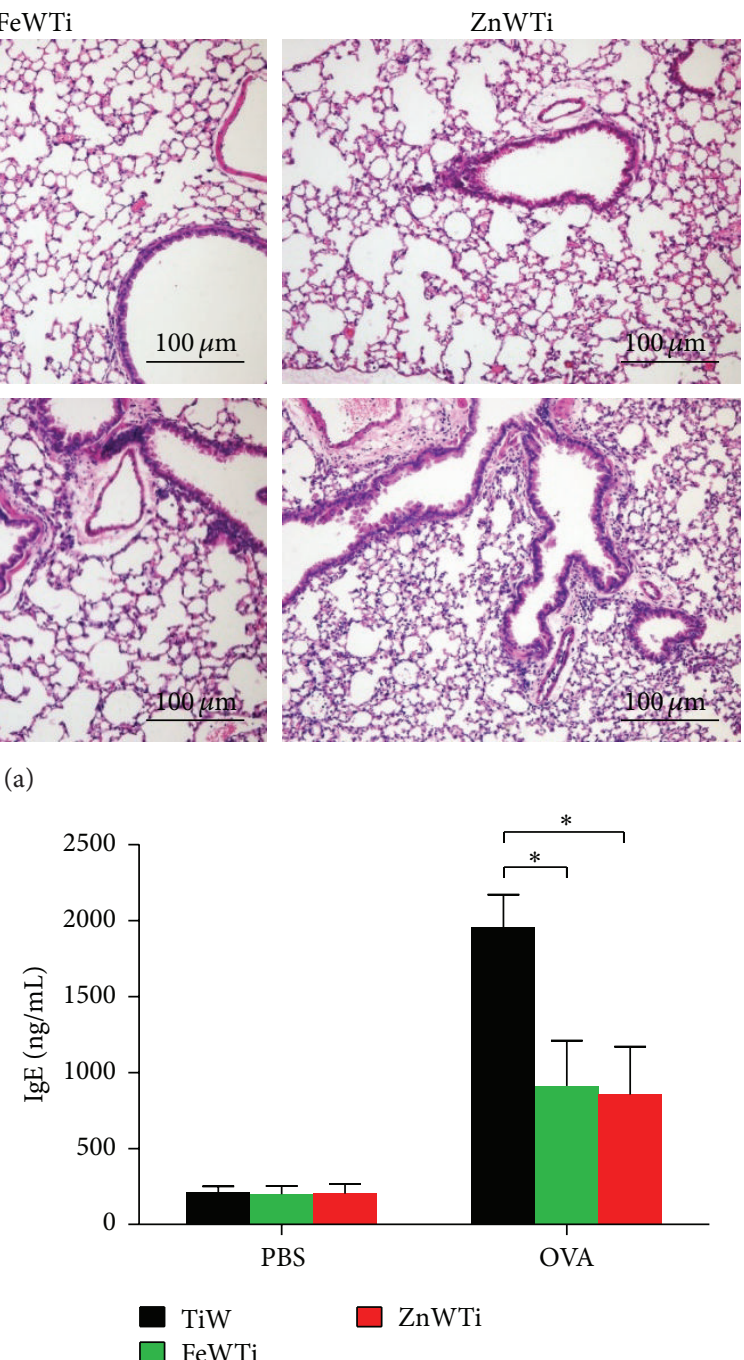

(c)

FIgURE 1: Polyoxometalates FeWTi and ZnWTi reduce OVA-induced lung inflammation. (a) Lung H\&E staining; (b) lung pathology score; (c) serum IgE level measured by ELISA; bars $=$ SEM; $n=7$ mice/group/experiment; scale bar $=100 \mu \mathrm{m} ;{ }^{*} p<0.05$ compared to mouse treated with TiW. Data are representative of 3 experiments.

3.3. Polyoxometalates FeWTi and ZnWTi Reduce Proinflammatory Cytokines in the BALF. After we established that FeWTi or ZnWTi treatment contributed to less severe lung inflammation and cell infiltration in OVA-induced asthma mouse model, we next investigate the mechanisms of this phenomenon by analyzing the cytokine profiles of BAL fluid. The levels of type 2 cytokines (IL-4, IL-5, and IL-13) and TNF$\alpha$ are significantly lower in FeWTi or ZnWTi treated mice compared to those in TiW treated mice, but the level of type 1 cytokine IFN- $\gamma$ is not significantly different (Figure 3 ).

3.4. Polyoxometalates FeWTi and ZnWTi Reduce mRNA Gene Expression of Proinflammatory Cytokines. Next, in order to identify the sources of cytokines which were reduced by POM treatments, we measured the mRNA expression profile of lung tissue. The results had similar trend with cytokine profile; type 2 cytokines like Il4, Il5, and Il13 and Tnf but not type 1 cytokine like Ifng are significantly lower in FeWTi or ZnWTi treated mice. These results indicate that inflammatory cells that infiltrated in the lung might cause the higher concentration of type 2 cytokines which was observed in the BAL fluid (Figure 4).

\section{Discussion}

In short, out work showed that using Ti-substituting POMs like FeWTi and ZnWTi could reduce inflammation and inflammatory cell infiltration in OVA-induced asthma murine model. This was also companied by the reduced proinflammatory cytokine production. To investigate the antiasthma potential of these two chemicals, we also tested their effect on mast cells, which played essential role in 


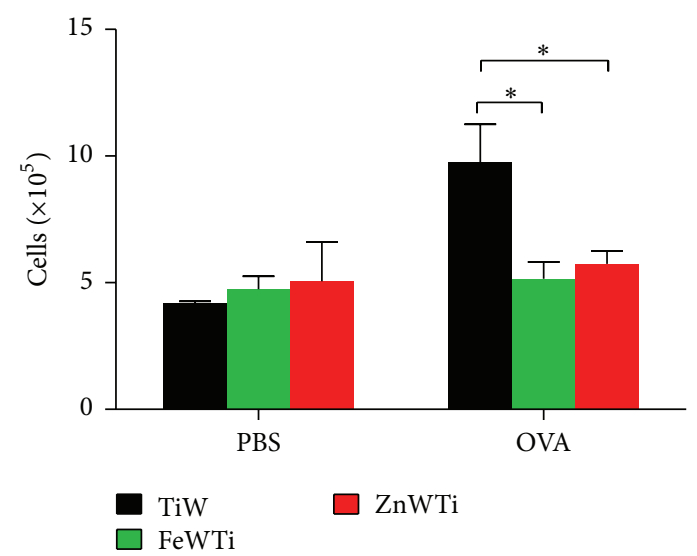

(a)

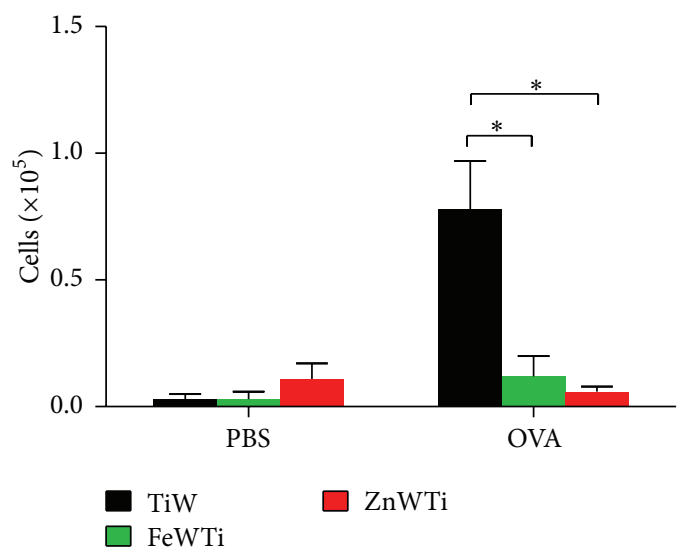

(c)

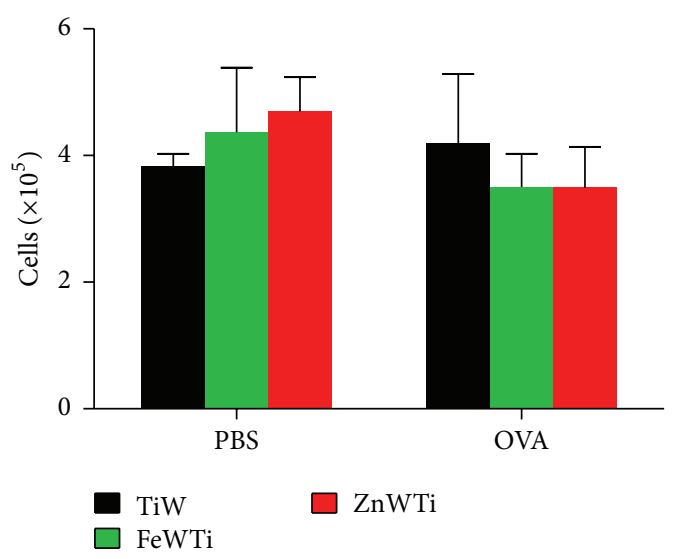

(b)

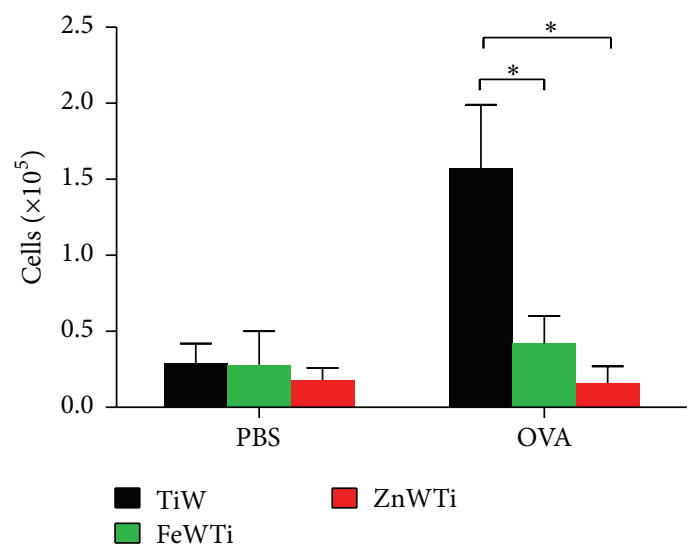

(d)

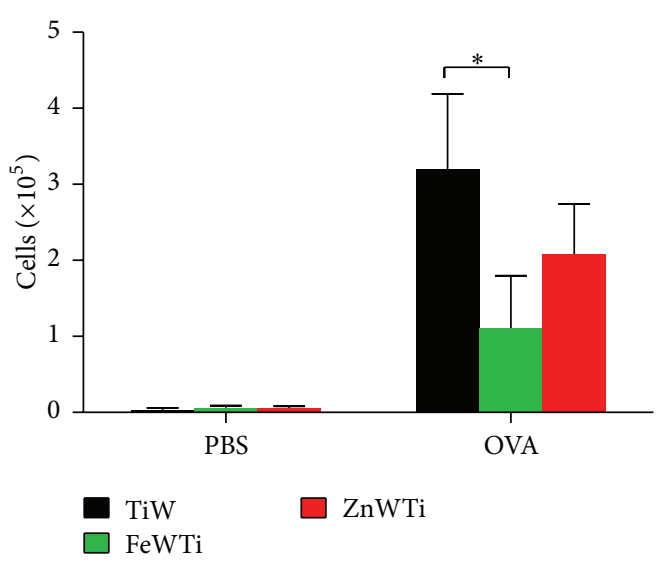

(e)

FIgURE 2: Polyoxometalates FeWTi and ZnWTi reduce inflammatory cells infiltration in the airway. Cells in the BALF were stained and counted; numbers of (a) total cells, (b) macrophages, (c) neutrophils, (d) lymphocytes, and (e) eosinophils; bars = SEM; $n=7$ mice/group/experiment; ${ }^{*} p<0.05$ compared to mouse treated with TiW. Data are representative of 3 experiments.

the asthmatic reactions. Both FeWTi and ZnWTi could significantly reduce the degranulation of mast cells but not TiW (Figure 5).

Asthma is still a major health threat despite decades of researches into it. And asthma exacerbation related hospitalization and readmission remain an unsolved issue. One of the reasons for this is $\beta$-adrenoceptor tolerance induced by repeated high dose usage [34]. The use of anti-inflammatory drugs is considered to be very effective initially, but their endocrine effects were proven to be controversial later [35, 36]. Recent approaches in the treatment of asthma were focused on the secondary consequences of asthma instead of the underlying mechanisms and aetiological causes of asthma, such as targeting mast cell, suppressing its activation 


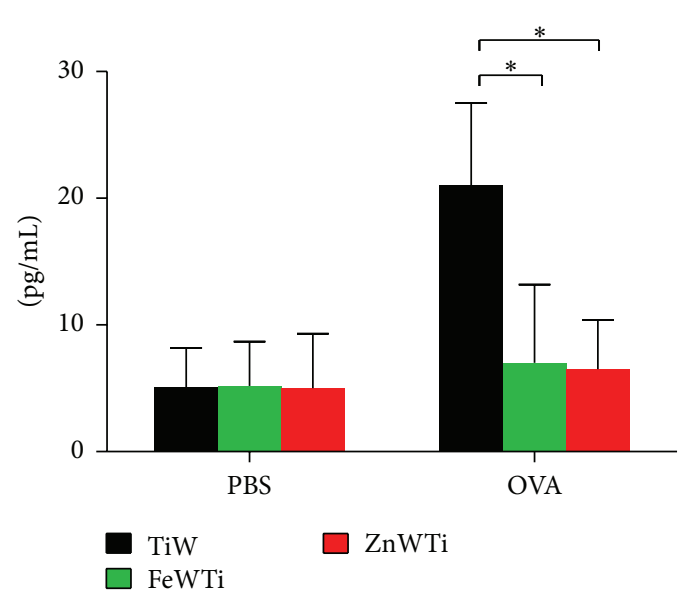

(a)

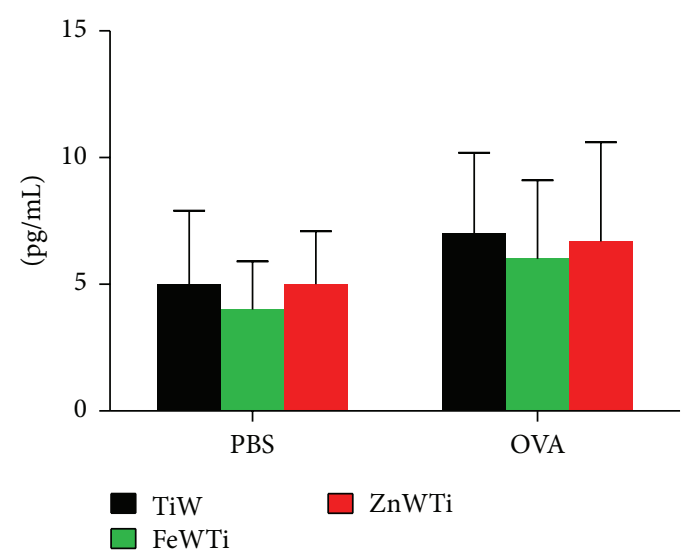

(c)

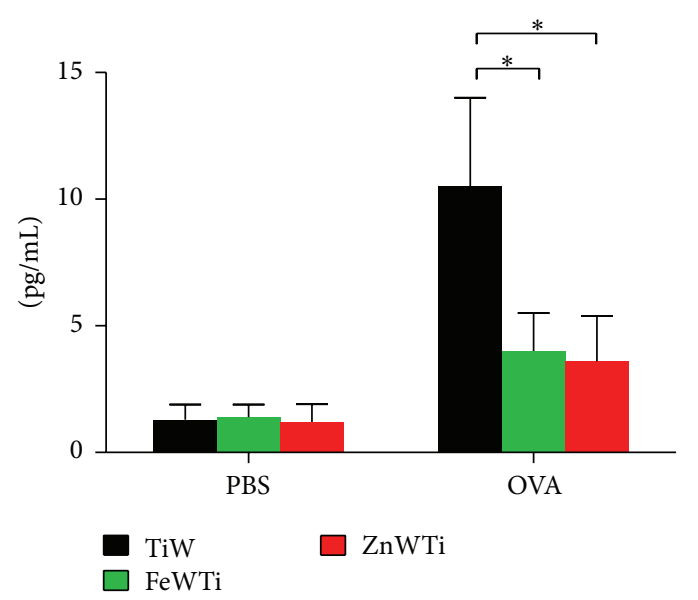

(b)

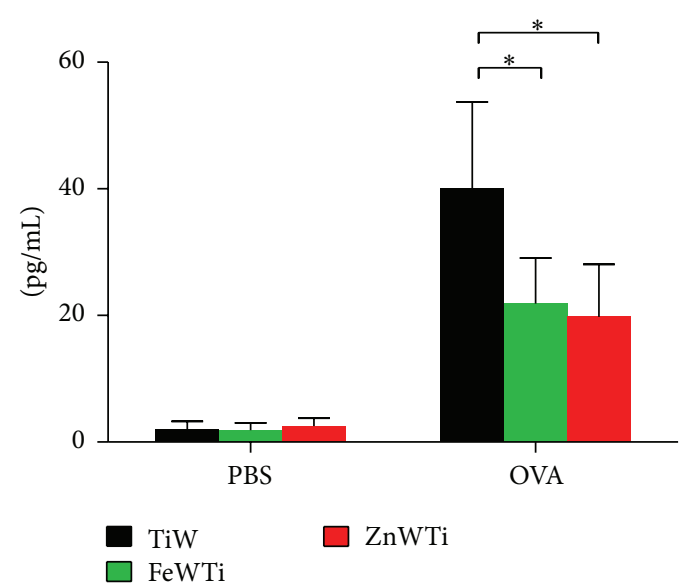

(d)

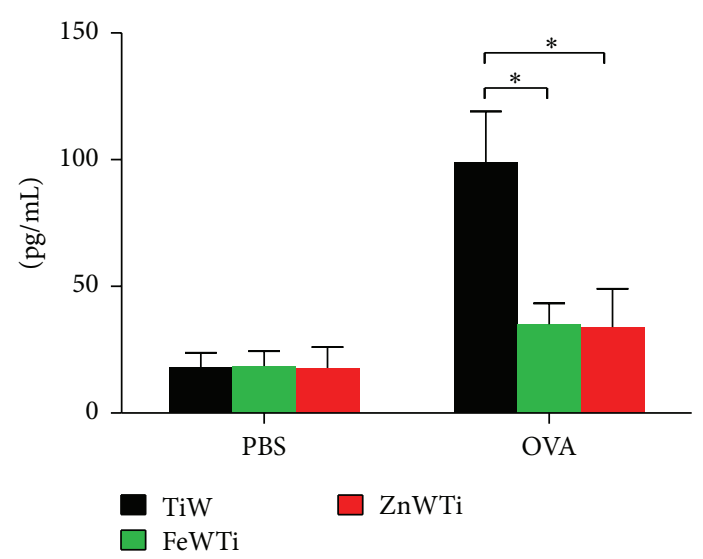

(e)

Figure 3: Polyoxometalates FeWTi and ZnWTi reduce inflammatory cytokines profile in OVA-induced asthma. Cytokines in the BALF were measured by ELISA; the concentration of (a) IL-4, (b) IL-5, (c) IFN- $\gamma$, (d) IL-13, and (e) TNF- $\alpha$; bars = SEM; $n=7$ mice/group/experiment; ${ }^{*} p<0.05$ compared to mouse treated with TiW. Data are representative of 3 experiments.

directly or indirectly via neutralizing IgE, or using histamine agonist. Target $\mathrm{T}$ helper cells, cytokines, or cytokine receptors are also considered, although their involvement in asthma is well established, but all these efforts have achieved limited success [37]. This may be due to the fact that asthma cannot be considered as a homogeneous disorder; different subtypes of asthma have already been identified. Therefore, more researches into the mechanisms of asthma and reagents with therapeutic value are required.

POMs have already been shown to have great potential of pharmaceutical value, as they have already been proven to have anticancer $[12,38]$ and antivirus $[7,39,40]$ activities. In 


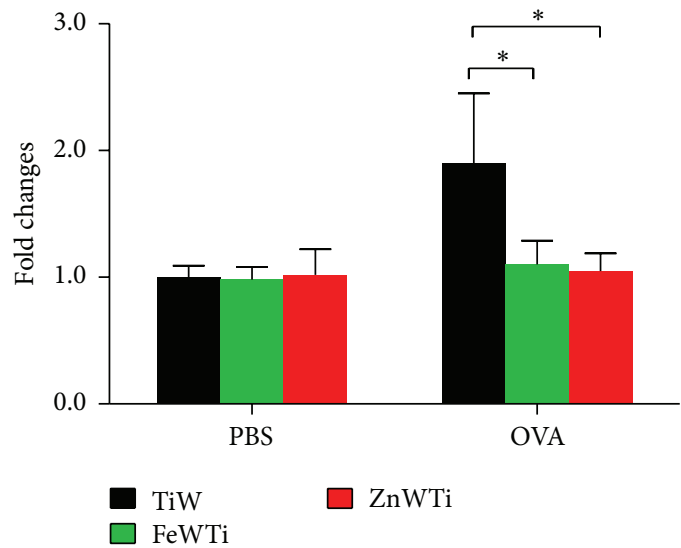

(a)

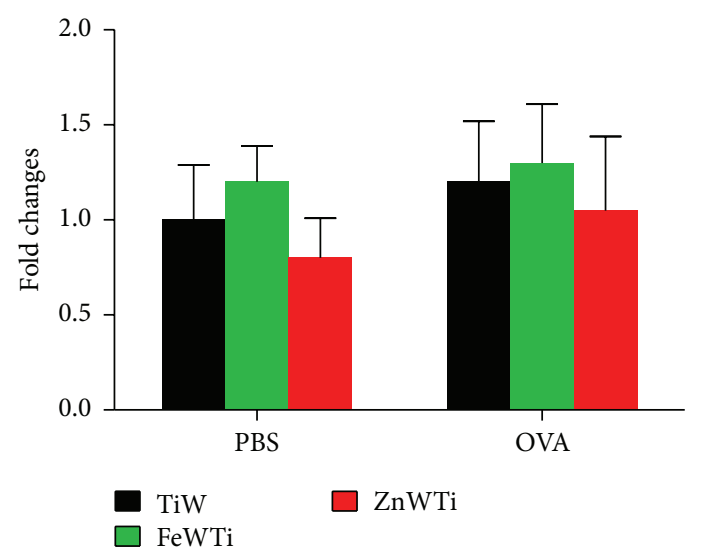

(c)

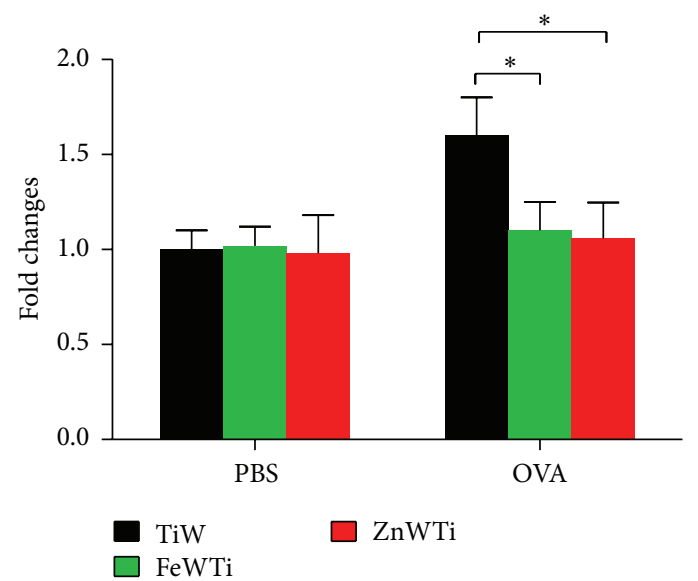

(b)

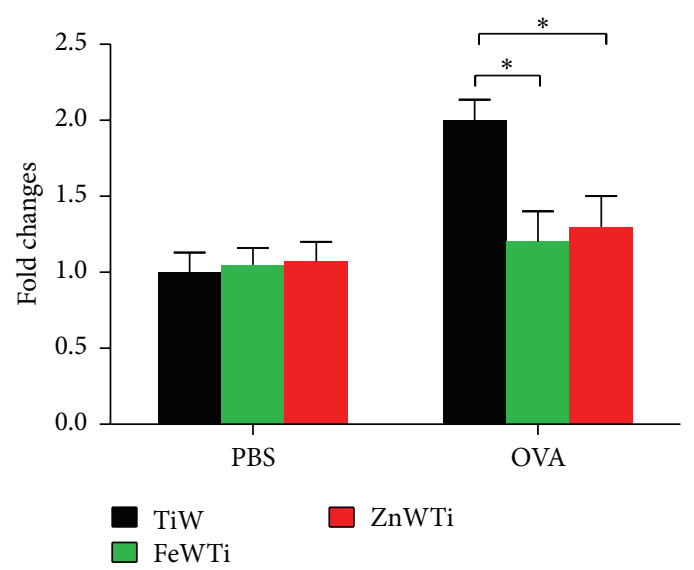

(d)

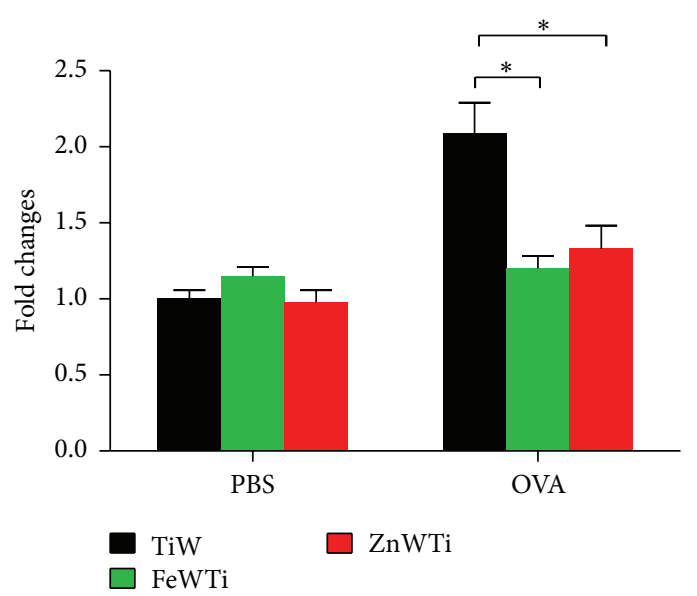

(e)

FIgURE 4: Polyoxometalates FeWTi and ZnWTi reduce mRNA expression of inflammatory cytokines in OVA-induced asthma. The mRNA expressions of cytokines of lung tissues were measured by q-PCR; the expression of (a) Il4, (b) Il5, (c) Ifng, (d) Ill3, and (e) Tnf; bars = SEM; $n=7$ mice/group/experiment; ${ }^{*} p<0.05$ compared to mouse treated with TiW. Data are representative of 3 experiments.

the reported results [10-14], titanium seems to be an important metal ion to afford antiviral action of polyoxotungstate in mice [17] and titanium-containing POMs are less toxic for actively growing cells than their vanadium containing counterparts [15]. Thus, titanium-containing POM may be safe and potent for therapeutic use in in vivo virus infections. In this work we used three titanium-containing POMs to investigate their antiasthma effects. The results showed that 


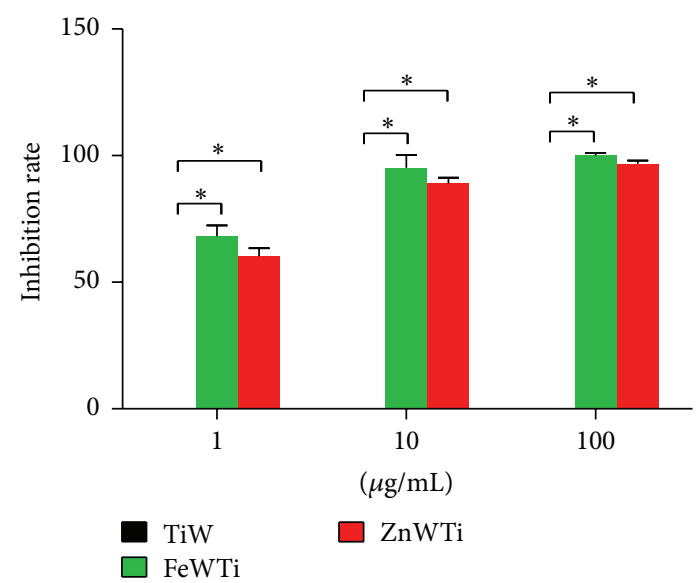

Figure 5: Polyoxometalates FeWTi and ZnWTi suppress the degranulation of mast cells. Mast cells were stimulated by ionomycin and PMA with or without different doses of TiW, FeWTi, or ZnWTi for 1 hour; the concentrations of histamine in supernatant were measured by ELISA. The inhibition rate was calculated by comparing the histamine expression of mast cells treated with different chemicals to mast cells treated with completed media. ${ }^{*} p<$ 0.05 compared to mouse treated with TiW. Data are representative of 3 experiments.

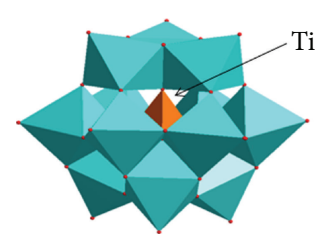

(a)

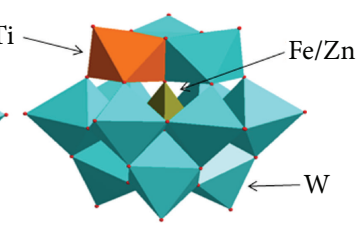

(b)
FIgURE 6: Keggin anion structure. (a) $\mathrm{TiW}_{12} \mathrm{O}_{40}{ }^{4-}$ and (b) $\mathrm{Fe}(\mathrm{Zn}) \mathrm{W}_{11} \mathrm{TiO}_{40}{ }^{5-/ 6-}$.

both titanium-substituted FeWTi and ZnWTi could reduce inflammation and inflammatory cell infiltrations in OVAinduced asthma murine model but TiW did not.

Why does not TiW have the exact antiasthma effects as FeWTi and ZnWTi do? The main reason is the site of the Ti atom in the anion. Three anions all have the Keggin anion structure (Figure 6). In TiW anion Ti atom as a heteroatom locates in the centre of anion and is surrounded by four triads of tungsten-oxo octahedra (Figure 6(a)). So this Ti atom does not contact with other materials in the environment. In FeWTi and ZnWTi anions the heteroatoms are $\mathrm{Fe}$ atom and $\mathrm{Zn}$ atom; $\mathrm{Ti}$ atom substitutes one of twelve $\mathrm{W}$ atoms (Figure 6(b)). Ti atom shares oxygen atoms with four $\mathrm{W}$ atoms and Fe or $\mathrm{Zn}$ atoms; its sixth coordination site may be occupied by a substitutable water molecule or other groups. The surrounding of the substituted atom (transition metal, here is Ti atom) is so similar to those of transition metal atom in porphyrin that the monosubstituted Keggin anion is called inorganic porphyrin analogue $[41,42]$. That is, Ti atom in the periphery of the anion has high reactivity.
To sum up, this work provides further evidences in the pharmaceutical potentials of Ti-substituted polyoxometalates. Particularly for asthmatic diseases, further researches into the mechanisms and potent side effects of this type of chemicals may provide novel therapeutic strategy.

\section{Additional Points}

(1) Ti-substituted polyoxometalates attenuate inflammations in an asthmatic setting. (2) Ti-substituted polyoxometalates reduce the production of type 2 cytokines like IL-4, IL-5, and IL-13.

\section{Competing Interests}

The authors declare that there are no competing financial interests.

\section{Acknowledgments}

This work was supported by the National Natural Science Foundation of China (no. 81501423) and Norman Bethune Program of Jilin University (no. 2015223).

\section{References}

[1] M. Pope, Y. Jeannin, and M. Fournier, Heteropoly and Isopoly Oxometalates, Springer, Berlin, Germany, 2013.

[2] M. T. Pope and A. Müller, "Polyoxometalate chemistry: an old field with new dimensions in several disciplines," Angewandte Chemie, vol. 30, no. 1, pp. 34-48, 1991.

[3] Y. G. Chen and J. F. Liu, "Heteropoly complexes containing titanium-I. The complexes with tetrahedral iron or chromium as central atom," Polyhedron, vol. 15, no. 19, pp. 3433-3436, 1996.

[4] Y.-G. Chen, Z. P. Zhu, Y. Y. Zhao, H. D. Wu, S.-Y. Li, and J. F. Liu, "Synthesis and redox properties of undecatungstotitanoheteropoly compounds MnXW11TIO40 center dot xH (2) $\mathrm{O}(\mathrm{X}=\mathrm{Si}, \mathrm{B}, \mathrm{Zn} ; \mathrm{M}=\mathrm{K}, \mathrm{H})$," Chinese Journal of Inorganic Chemistry, vol. 15, no. 2, pp. 205-210, 1999.

[5] L.-X. Shi, W.-F. Zhao, X. Xu, J. Tang, and C.-D. $\mathrm{Wu}$, "From $1 \mathrm{D}$ to $3 \mathrm{D}$ single-crystal-to-single-crystal structural transformations based on linear polyanion $\left[\mathrm{Mn}_{4}\left(\mathrm{H}_{2} \mathrm{O}\right)_{18} \mathrm{WZnMn}_{2}\left(\mathrm{H}_{2} \mathrm{O}\right)_{2}\left(\mathrm{ZnW}_{9} \mathrm{O}_{34}\right)_{2}\right]^{4-}$," Inorganic Chemistry, vol. 50, no. 24, pp. 12387-12389, 2011.

[6] L. C. W. Baker, V. S. Baker, K. Eriks et al., "A new general structural category of heteropolyelectrolytes. Unusual magnetic and thermal contraction phenomena," Journal of the American Chemical Society, vol. 88, no. 10, pp. 2329-2331, 1966.

[7] J. T. Rhule, C. L. Hill, D. A. Judd, and R. F. Schinazi, "Polyoxometalates in medicine," Chemical Reviews, vol. 98, no. 1, pp. 327-357, 1998.

[8] M. Aureliano, "Decavanadate toxicology and pharmacological activities: V10 or v1, both or none?" Oxidative Medicine and Cellular Longevity, vol. 2016, Article ID 6103457, 8 pages, 2016.

[9] A. Maalaoui, A. Hajsalem, N. Ratel-Ramond, and S. Akriche, "Synthesis, characterization and antibacterial activity of a novel photoluminescent nb-substituted lindqvist polyoxotungstate based organic cation," Journal of Cluster Science, vol. 25, no. 6, pp. 1525-1539, 2014. 
[10] H. S. Shah, R. Al-Oweini, A. Haider, U. Kortz, and J. Iqbal, "Cytotoxicity and enzyme inhibition studies of polyoxometalates and their chitosan nanoassemblies," Toxicology Reports, vol. 1, pp. 341-352, 2014.

[11] M. Aureliano, C. A. Ohlin, M. O. Vieira, M. P. Marques, W. H. Casey, and L. A. Batista de Carvalho, "Characterization of decavanadate and decaniobate solutions by Raman spectroscopy," Dalton Transactions, vol. 45, no. 17, pp. 7391-7399, 2016.

[12] T. Yamase, N. Fukuda, and Y. Tajima, "Synergistic effect of polyoxotungstates in combination with $\beta$-lactam antibiotics on antibacterial activity against methicillin-resistant Staphylococcus aureus," Biological and Pharmaceutical Bulletin, vol. 19, no. 3, pp. 459-465, 1996.

[13] N. Fukuda, T. Yamase, and Y. Tajima, "Inhibitory effect of polyoxotungstates on the production of penicillin- binding proteins and $\beta$-lactamase against methicillin-resistant Staphylococcus aureus," Biological and Pharmaceutical Bulletin, vol. 22, no. 5, pp. 463-470, 1999.

[14] M. Inoue, T. Suzuki, Y. Fujita, M. Oda, N. Matsumoto, and T. Yamase, "Enhancement of antibacterial activity of $\beta$-lactam antibiotics by $\left[\mathrm{P}_{2} \mathrm{~W}_{18} \mathrm{O}_{62}\right]^{6-},\left[\mathrm{SiMo}_{12} \mathrm{O}_{40}\right]^{4-}$, and $\left[\mathrm{PTi}_{2} \mathrm{~W}_{10} \mathrm{O}_{40}\right]^{7-}$ against methicillin-resistant and vancomycinresistant Staphylococcus aureus," Journal of Inorganic Biochemistry, vol. 100, no. 7, pp. 1225-1233, 2006.

[15] S. Shigeta, S. Mori, E. Kodama, J. Kodama, K. Takahashi, and T. Yamase, "Broad spectrum anti-RNA virus activities of titanium and vanadium substituted polyoxotungstates," Antiviral Research, vol. 58, no. 3, pp. 265-271, 2003.

[16] S. Shigeta, S. Mori, J. Watanabe et al., "In vitro antimyxovirus and anti-human immunodeficiency virus activities of polyoxometalates," Antiviral Chemistry \& Chemotherapy, vol. 6, no. 2, pp. 114-122, 1995.

[17] S. Ikeda, S. Nishiya, A. Yamamoto, T. Yamase, C. Nishimura, and E. De Clercq, "Activity of the Keggin polyoxotungstate PM19 against herpes simplex virus type 2 infection in immunosuppressed mice: role of peritoneal macrophage activation," Journal of Medical Virology, vol. 41, no. 3, pp. 191-195, 1993.

[18] K. Dan and T. Yamase, "Prevention of the interaction between HVEM, herpes virus entry mediator, and gD, HSV envelope protein, by a Keggin polyoxotungstate, PM-19," Biomedicine and Pharmacotherapy, vol. 60, no. 4, pp. 169-173, 2006.

[19] S. S. Braman, "The global burden of asthma," Chest, vol. 130, no. 1, supplement, pp. 4S-12S, 2006.

[20] T. A. E. Platts-Mills, “The allergy epidemics: 1870-2010," Journal of Allergy and Clinical Immunology, vol. 136, no. 1, pp. 3-13, 2015.

[21] S. J. Galli, "The mast cell-IgE paradox: from homeostasis to anaphylaxis," American Journal of Pathology, vol. 186, no. 2, pp. 212-224, 2016.

[22] M. Urb and D. C. Sheppard, "The role of mast cells in the defence against pathogens," PLoS Pathogens, vol. 8, no. 4, Article ID e1002619, 2012.

[23] U. M. Zissler, J. Esser-von Bieren, C. A. Jakwerth, A. M. Chaker, and C. B. Schmidt-Weber, "Current and future biomarkers in allergic asthma," Allergy, vol. 71, no. 4, pp. 475-494, 2016.

[24] G. Eberl, J. P. Di Santo, and E. Vivier, "The brave new world of innate lymphoid cells," Nature Immunology, vol. 16, no. 1, pp. 15, 2015.

[25] H. Y. Kim, D. T. Umetsu, and R. H. Dekruyff, "Innate lymphoid cells in asthma: will they take your breath away?" European Journal of Immunology, vol. 46, no. 4, pp. 795-806, 2016.

[26] K. F. Chung, "Targeting the interleukin pathway in the treatment of asthma," The Lancet, vol. 386, no. 9998, pp. 1086-1096, 2015.
[27] C. H. Fanta, "Asthma," The New England Journal of Medicine, vol. 360, no. 10, pp. 1002-1014, 2009.

[28] J. Domínguez-Ortega, E. Phillips-Anglés, P. Barranco, and S. Quirce, "Cost-effectiveness of asthma therapy: a comprehensive review," Journal of Asthma, vol. 52, no. 6, pp. 529-537, 2015.

[29] D. Li, R. Guabiraba, A.-G. Besnard et al., "IL-33 promotes ST2-dependent lung fibrosis by the induction of alternatively activated macrophages and innate lymphoid cells in mice," Journal of Allergy and Clinical Immunology, vol. 134, no. 6, pp. 1422-1432.e11, 2014.

[30] P. N. Pushparaj, D. Li, M. Komai-Koma et al., "Interleukin-33 exacerbates acute colitis via interleukin-4 in mice," Immunology, vol. 140, no. 1, pp. 70-77, 2013.

[31] M. Kurowska-Stolarska, B. Stolarski, P. Kewin et al., "IL33 amplifies the polarization of alternatively activated macrophages that contribute to airway inflammation," Journal of Immunology, vol. 183, no. 10, pp. 6469-6477, 2009.

[32] B. Stolarski, M. Kurowska-Stolarska, P. Kewin, D. Xu, and F. Y. Liew, "IL-33 exacerbates eosinophil-mediated airway inflammation," Journal of Immunology, vol. 185, no. 6, pp. 3472-3480, 2010.

[33] R. A. Johnston, M. Zhu, Y. M. Rivera-Sanchez et al., "Allergic airway responses in obese mice," American Journal of Respiratory and Critical Care Medicine, vol. 176, no. 7, pp. 650-658, 2007.

[34] N. Pearce, J. Crane, C. Burgess, R. Beasley, and R. Jackson, "Beta-agonists and death from asthma," The New England Journal of Medicine, vol. 327, no. 5, pp. 355-357, 1992.

[35] F. Cerasoli Jr., "Developing the ideal inhaled corticosteroid," Chest, vol. 130, no. 1, supplement, pp. 54S-64S, 2006.

[36] G. P. Currie, J. G. Douglas, and L. G. Heaney, "Difficult to treat asthma in adults," British Medical Journal, vol. 338, no. 7694, pp. 593-597, 2009.

[37] S. T. Holgate, "Stratified approaches to the treatment of asthma," British Journal of Clinical Pharmacology, vol. 76, no. 2, pp. 277291, 2013.

[38] S. Mitsui, A. Ogata, H. Yanagie et al., "Antitumor activity of polyoxomolybdate, $\left[\mathrm{NH}_{3} \mathrm{Pri}\right]_{6}\left[\mathrm{Mo}_{7} \mathrm{O}_{24}\right] \bullet{ }_{3} \mathrm{H}_{2} \mathrm{O}$, against, human gastric cancer model," Biomedicine and Pharmacotherapy, vol. 60, no. 7, pp. 353-358, 2006.

[39] D. L. Barnard, C. L. Hill, T. Gage et al., "Potent inhibition of respiratory syncytial virus by polyoxometalates of several structural classes," Antiviral Research, vol. 34, no. 1, pp. 27-37, 1997.

[40] J. Liu, W.-J. Mei, A.-W. Xu, C.-P. Tan, S. Shi, and L.-N. Ji, "Synthesis, characterization and antiviral activity against influenza virus of a series of novel manganese-substituted rare earth borotungstates heteropolyoxometalates," Antiviral Research, vol. 62, no. 1, pp. 65-71, 2004.

[41] D. E. Katsoulis and M. T. Pope, "New chemistry for heteropolyanions in anhydrous nonpolar solvents. Coordinative unsaturation of surface atoms. Polyanion oxygen carriers," Journal of the American Chemical Society, vol. 106, no. 9, pp. 2737-2738, 1984.

[42] D. K. Lyon, W. K. Miller, T. Novet et al., "Highly oxidation resistant inorganic-porphyrin analog polyoxometalate oxidation catalysts. 1 . The synthesis and characterization of aqueous-soluble potassium salts of .alpha. 2-P2W17O61(Mn+.cntdot.OH2) $(n-10)$ and organic solvent soluble tetra-n-butylammonium salts of .alpha. 2-P2W17O61(Mn+.cntdot.Br $)(n-11)(\mathrm{M}=\mathrm{Mn} 3+, \mathrm{Fe} 3+, \mathrm{Co} 2+$, $\mathrm{Ni2}+\mathrm{Cu} 2+)$," Journal of the American Chemical Society, vol. 113, no. 19, pp. 7209-7221, 1991. 

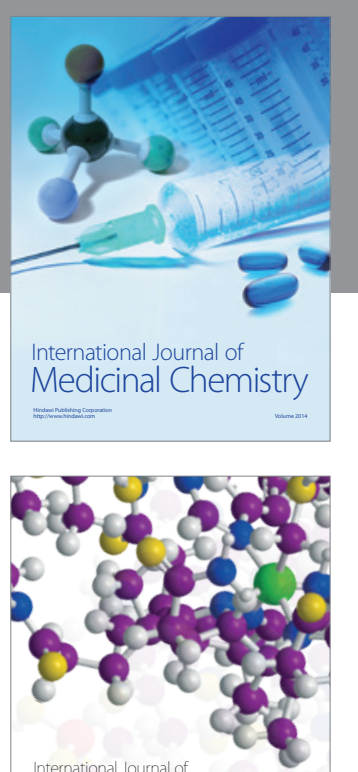

Carbohydrate Chemistry

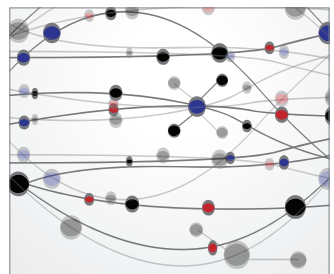

The Scientific World Journal
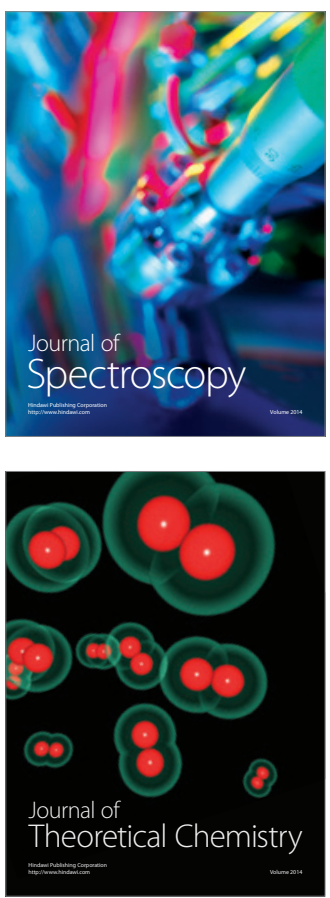
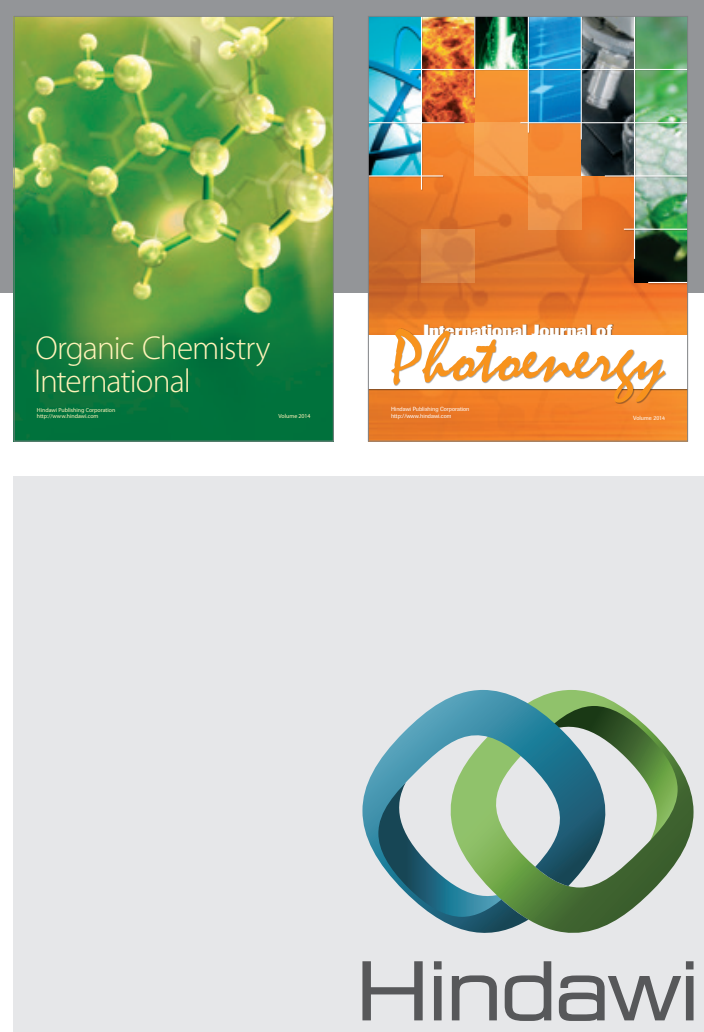

Submit your manuscripts at

http://www.hindawi.com

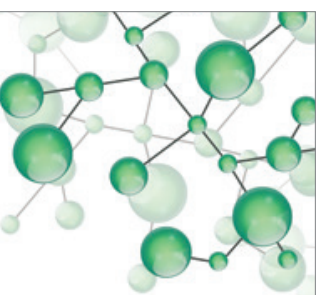

International Journal of

Inorganic Chemistry

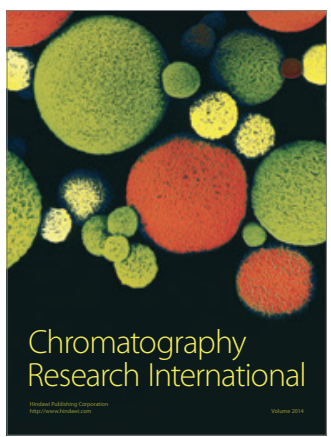

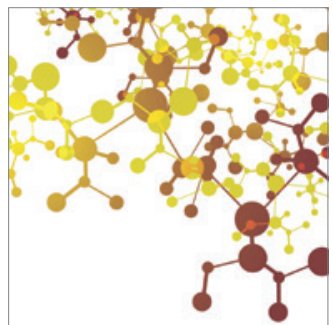

Applied Chemistry
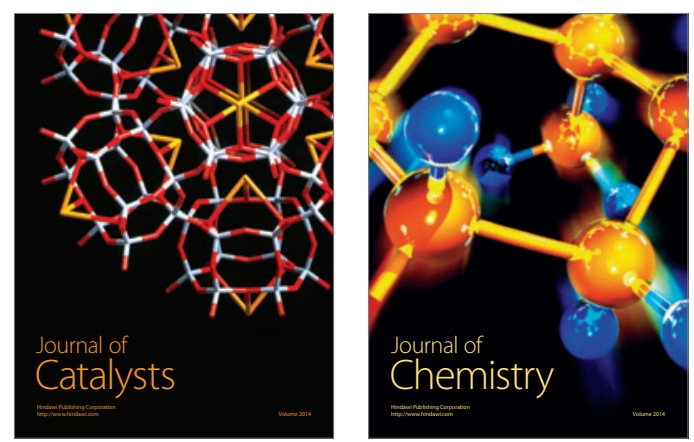
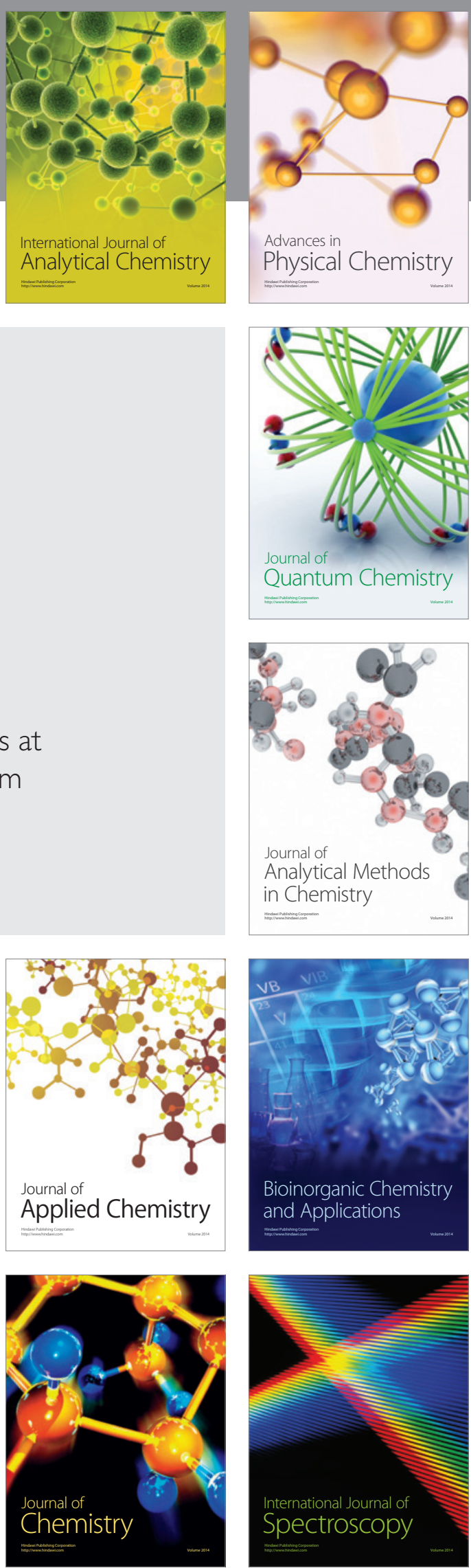